\title{
INTENSITY OF PRODUCTION ORGANIZATION AND TECHNICAL EQUIPMENT OF POLISH AGRICULTURE
}

\section{Krzysztof MAZUREK, Edmund LORENCOWICZ}

Department of Machinery Exploitation and Management of Production Processes, University of Life Sciences in Lublin, POLAND

E-mail of corresponding author: krzmaz7@wp.pl

Keywords: organization intensity, farm equipment, fixed assets, sustainable agriculture

\begin{abstract}
The work presents the relationship between the intensity of production organization and technical equipment of Polish agriculture. The intensity of production organization was determined using B. Kopeć's indicator method. Updates have been introduced to this method in order to reflect the changes that have occurred in Polish agriculture in the last thirty years. The state of farm mechanization and its changes were determined on the basis of the data collected by the Central Statistical Office (GUS) of Poland. The relationship between agriculture organization intensity and the basic indicators characterizing farm mechanization was analyzed.
\end{abstract}

\section{INTRODUCTION}

Since intensity is a qualitative phenomenon, it is unmeasurable. The intensity of agriculture organization can be evaluated using a point scale. Such a scale takes into consideration the share of high-input crops in the crop structure, and the number of livestock units per unit of area. One of the methods used for determining agricultural organization intensity is the indicator method developed by B. Kopeć in the 1950s. The first publication presenting this method appeared in 1958 (Kopeć 1958) and the last in 1987 (Kopeć 1987). Kopeć's method is used by numerous Polish authors (Figurski, Lorencowicz 2010; Jankowski, Bieńkowski, Holka 2010; Kluba, Rudnicki, Wiśniewski 2016; Kocira 2009; Kołtun 2014; Kopiński 2009; Lorencowicz 2009; Malaga-Toboła, Kocira 2013; Parafiniuk 2013; Polna 2009; Sawa 2009; Szeląg-Sikora 2008; SzelągSikora, Cupiał, Niemiec 2015; Szuk 2009; Żak 2013), which proves its usefulness.

The objective of the research is to determine the relationship between the intensity of production organization and the technical equipment of Polish agriculture.

\section{METHODS}

Over the past twenty years, significant changes, both economic and technological, have occurred in Polish agriculture. There has been a significant increase of cultivated plant yields, an increase of productivity in animal production, as well as changes concerning fertilization and farm mechanization (Tab. 1).

Tab. 1. Selected parameters characterizing the changes in Polish agriculture over 1995-2015

\begin{tabular}{|l|c|c|c|c|}
\hline \multicolumn{1}{|c|}{ Specification } & Unit & 1995 & 2015 & $\begin{array}{c}\text { Change } \\
1995-2015\end{array}$ \\
\hline Yield of five basic cereals & $\mathrm{dt} / \mathrm{ha}$ & 30.6 & 37.9 & $24 \%$ \\
\hline Sugar beet yield & $\mathrm{dt} / \mathrm{ha}$ & 344 & 520 & $51 \%$ \\
\hline Potato yield & $\mathrm{dt} / \mathrm{ha}$ & 164 & 210 & $28 \%$ \\
\hline Annual milk yield per one cow & thousands of liters & 3136 & 5164 & $65 \%$ \\
\hline Average annual number of eggs per one hen & $\mathrm{pcs}$ & 163 & 231 & $42 \%$ \\
\hline NPK mineral fertilizers & $\mathrm{kg} / \mathrm{ha}$ & 76.6 & 123.2 & $61 \%$ \\
\hline Utilized agricultural area (UAA) per one tractor & $\mathrm{ha}$ & 13.6 & $10.2 *$ & $-25 \%$ \\
\hline Installed power of tractors & $\mathrm{kW} / 100 \mathrm{ha}$ & 229.4 & $416.7^{*}$ & $82 \%$ \\
\hline
\end{tabular}

*2013 data.

Source: Central Statistical Office of Poland, GUS (1995-2016). 
Therefore, it was necessary to update Kopeć's method (Lorencowicz, Mazurek, Kocira 2017). Taking into consideration selected factors which characterize agriculture, changes were proposed to point ranges determining the degree of intensity (degrees of development). An application has been developed in the spreadsheet for calculating the intensity and its level for particular provinces of Poland in 1995-2015 (Fig.1). The results obtained show the intensity level according to the original Kopeć's method (hereinafter referred to as "K'1987") and after its update ("K'2017").

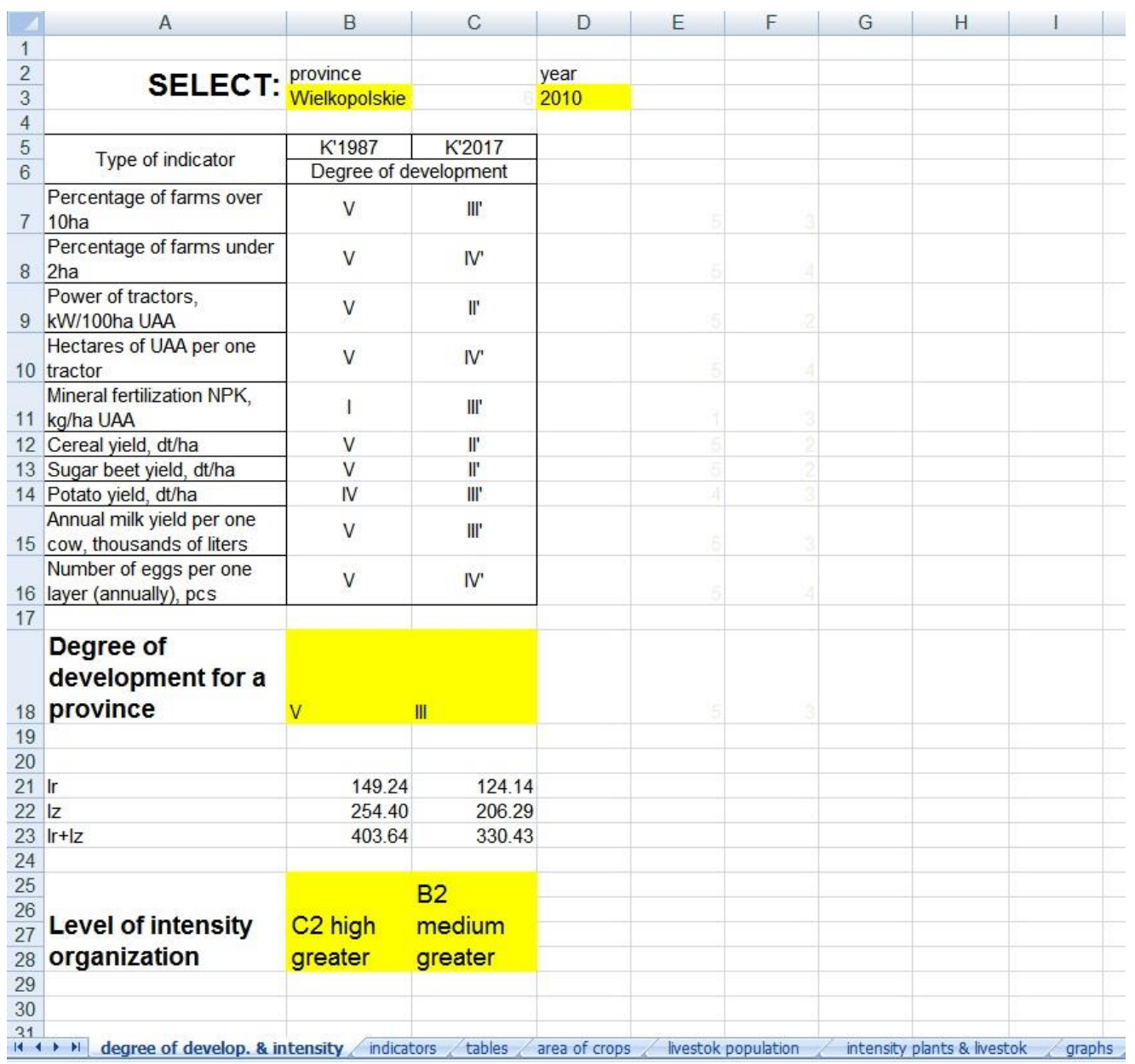

Fig. 1. Application determining intensity level of agriculture organization for provinces in 1987-2017

Farm mechanization changes were determined using the following indicators:

- $\quad$ installed power of tractors [kW/100 ha]

- $\quad$ utilized agricultural area (UAA) per one tractor [ha/tractor]

- $\quad$ number of combine harvesters per 100 ha [combines/100 ha]

The data used in the analyses were obtained from the database of the Central Statistical Office of Poland (GUS 1995-2016). For most of the parameters analyzed, the data availability covered the entire period under investigation, yet in some cases data from selected years were unavailable, which made interpretation of the results difficult.

\section{RESULTS}

In the period under review, there were significant changes in the intensity of the agriculture organization. In 2006-2015 (Fig. 2) the intensity of the agriculture organization in Poland increased by $13.8 \%$ as measured by the original method (K'1987) 
or by $16 \%$ as measured by the updated method (K'2017). In both cases, there is a noticeable increase in intensity; however, the point ranges are different, which essentially illustrates the changes in the method.

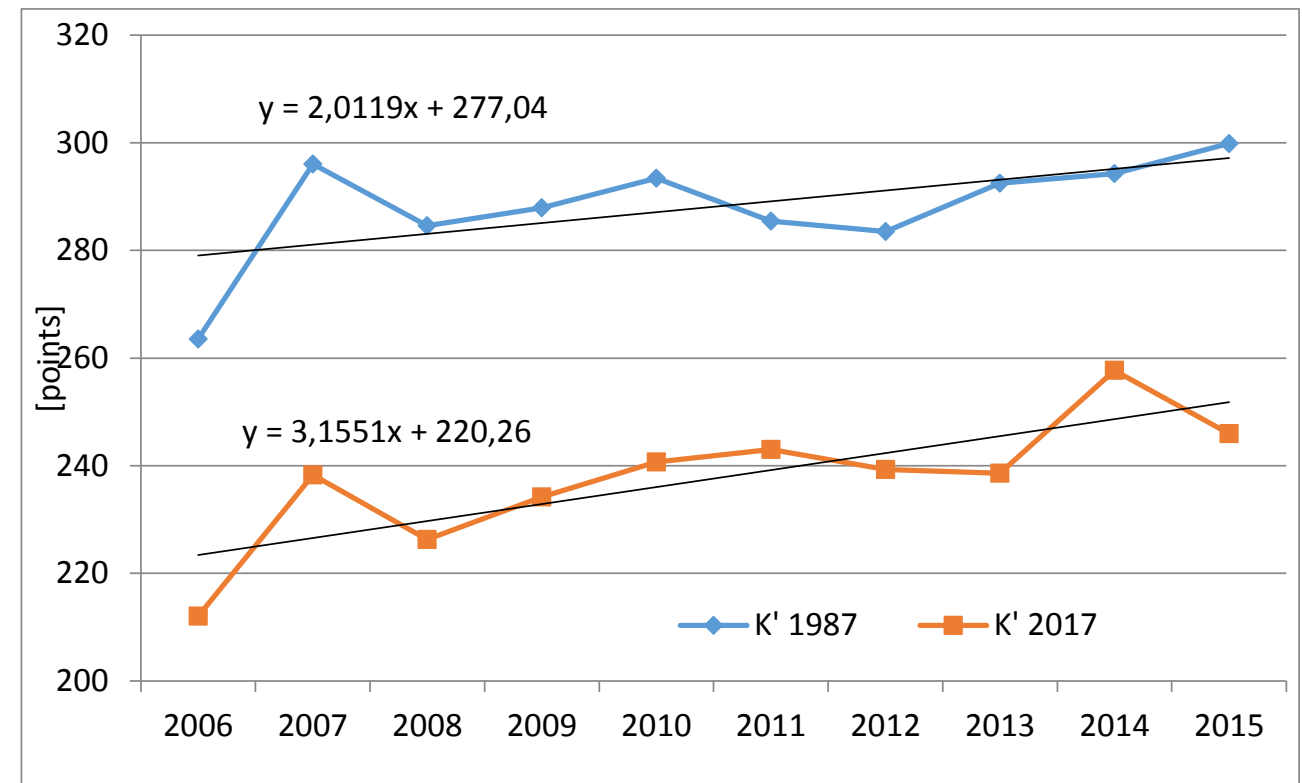

Fig. 2 Intensity of production organization in Poland in 2006-2015

Detailed results of studies in the intensity of agriculture organization for particular provinces are presented in Tab. 2. As it is in the graph, intensity fluctuations are noticeable, but the general trend is increasing.

Tab. 2. Summary of the results of the intensity agriculture organization assessment according to the original (K'1987) and updated (K'2017) method for particular provinces in 2006-2015

\begin{tabular}{|c|c|c|c|c|c|c|}
\hline \multirow[t]{2}{*}{ Province } & \multicolumn{2}{|l|}{2006} & \multicolumn{2}{|l|}{2015} & \multirow{2}{*}{$\begin{array}{l}\text { Change } \\
\text { K'1987 }\end{array}$} & \multirow{2}{*}{$\begin{array}{l}2006- \\
2015 \\
K^{\prime} 2017\end{array}$} \\
\hline & K'1987 & K'2017 & K'1987 & K'2017 & & \\
\hline Dolnośląskie & 204.3 & 168.9 & 206.7 & 171.2 & $1 \%$ & $1 \%$ \\
\hline Kujawsko-pomorskie & 372.0 & 254.7 & 343.2 & 256.6 & $-8 \%$ & $1 \%$ \\
\hline Lubelskie & 187.5 & 172.5 & 232.5 & 192.6 & $24 \%$ & $12 \%$ \\
\hline Lubuskie & 124.0 & 149.9 & 207.4 & 155.1 & $67 \%$ & $3 \%$ \\
\hline Łódzkie & 211.9 & 211.9 & 319.0 & 263.4 & $51 \%$ & $24 \%$ \\
\hline Małopolskie & 169.1 & 169.1 & 221.6 & 180.8 & $31 \%$ & $7 \%$ \\
\hline Mazowieckie & 292.6 & 200.5 & 310.7 & 231.0 & $6 \%$ & $15 \%$ \\
\hline Opolskie & 279.9 & 208.7 & 271.2 & 271.2 & $-3 \%$ & $30 \%$ \\
\hline Podkarpackie & 139.3 & 127.7 & 186.2 & 139.1 & $34 \%$ & $9 \%$ \\
\hline Podlaskie & 316.8 & 234.9 & 356.6 & 265.3 & $13 \%$ & $13 \%$ \\
\hline Pomorskie & 258.8 & 191.8 & 253.0 & 208.3 & $-2 \%$ & $9 \%$ \\
\hline Śląskie & 224.8 & 166.6 & 255.8 & 210.7 & $14 \%$ & $26 \%$ \\
\hline Świętokrzyskie & 180.3 & 180.3 & 260.7 & 178.9 & $45 \%$ & $-1 \%$ \\
\hline Warmińsko-mazurskie & 249.6 & 206.3 & 240.0 & 198.6 & $-4 \%$ & $-4 \%$ \\
\hline Wielkopolskie & 310.2 & 286.5 & 420.4 & 386.3 & $36 \%$ & $35 \%$ \\
\hline Zachodniopomorskie & 165.2 & 123.6 & 186.4 & 153.5 & $13 \%$ & $24 \%$ \\
\hline Mean value & 263.6 & 212.0 & 299.9 & 246.0 & $14 \%$ & $16 \%$ \\
\hline
\end{tabular}

The increase of UAA per 1 tractor (Fig. 3) can be attributed both to the increase in the farm acreage and to the purchase of more powerful tractors than those used previously. 


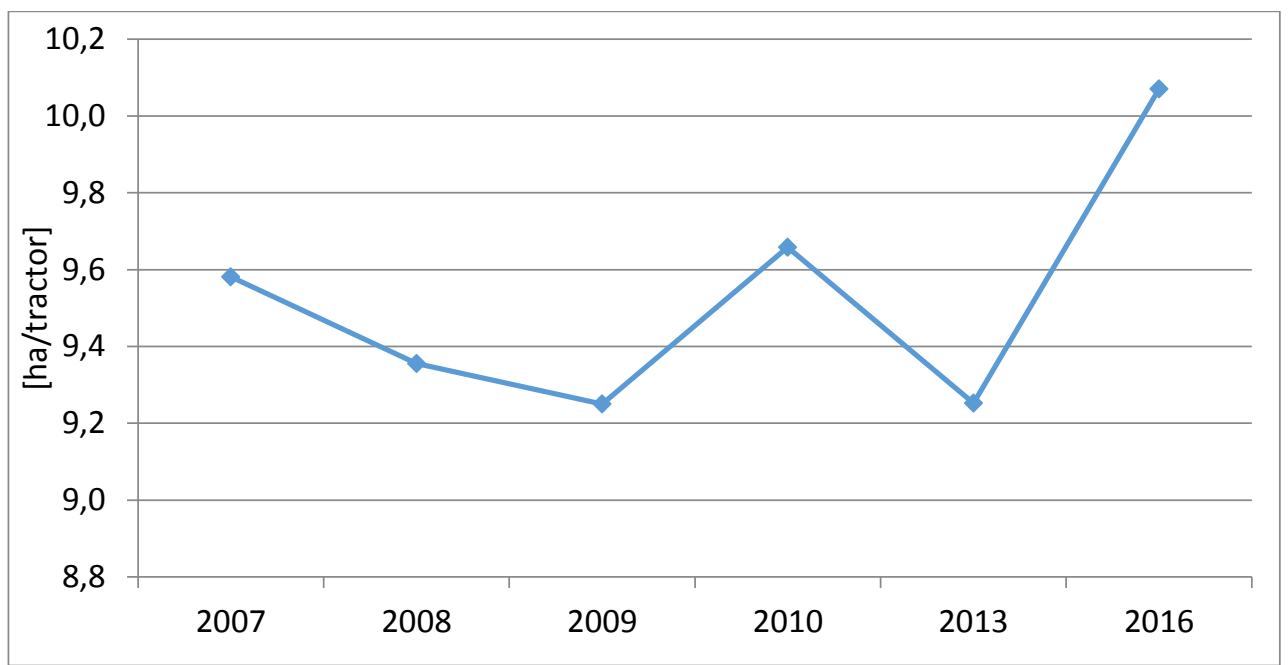

Fig. 3. Utilized agricultural area per one tractor in Poland in 2007-2016

In most of the cases observed, the number of combine harvesters per 100ha (Fig.4) increases. This may indicate a constant demand for these machines in the Polish farms as well as an increasing profitability of smaller farms for which owning a combine harvester had not been possible before for economic reasons. On average, there are 2 combine harvesters per 100 ha UAA in Poland.

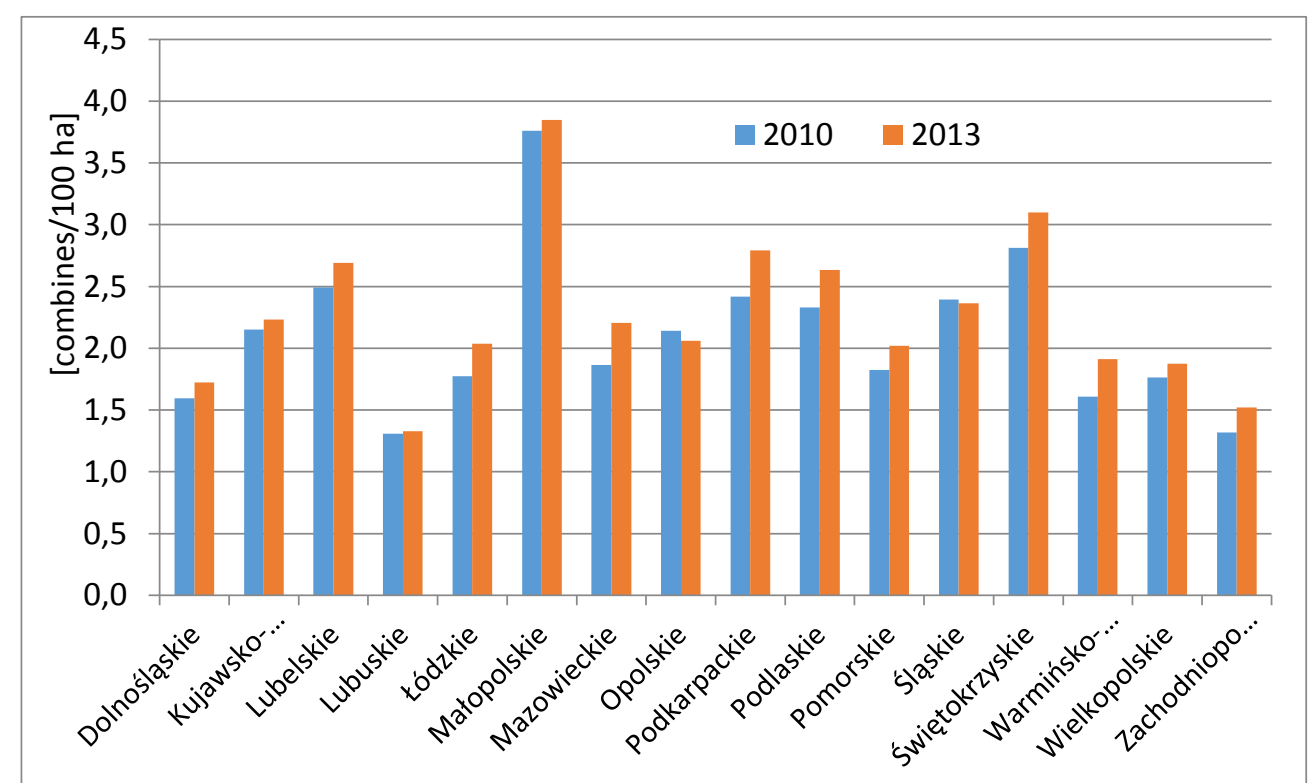

Fig. 4. Number of combine harvesters per 100 ha of cereals in particular provinces of Poland in 2010 and 2013

The installed power of tractors increased from $2.1 \%$ up to even $22.5 \%$ depending on the province. The change dynamics of this indicator is varied and it is in no direct relation to the production organization intensity in agriculture.

The graphs and tables presented show the general increase in the value of installed power indicators. By comparing the values of the indices directly with the values of production intensity, it is not possible to determine unequivocally the relationships between the traits under examination. 
Tab. 3. Installed power of tractors in $\mathrm{kW} / 100 \mathrm{ha}$ and intensity of production organization in particular provinces of Poland in 2007-2013

\begin{tabular}{|l|c|c|c|c|c|c|c|c|}
\hline \multirow{2}{*}{ Province } & 2007 & 2007 & 2010 & 2010 & 2013 & 2013 & \multicolumn{2}{c|}{$\begin{array}{c}\text { Change } \\
2007-2013 \text { in } \%\end{array}$} \\
\cline { 2 - 9 } & $\mathrm{kW} / 100 \mathrm{ha}$ & points & $\mathrm{kW} / 100 \mathrm{ha}$ & points & $\mathrm{kW} / 100 \mathrm{ha}$ & $\mathrm{points}$ & $\mathrm{kW} / 100 \mathrm{ha}$ & points \\
\hline Dolnośląskie & 258.4 & 168.3 & 226.5 & 162.0 & 264.0 & 164.7 & $2.1 \%$ & $-2.1 \%$ \\
\hline Kujawsko-pomorskie & 337.3 & 298.1 & 308.2 & 324.6 & 360.2 & 280.3 & $6.8 \%$ & $-6.9 \%$ \\
\hline Lubelskie & 473.8 & 178.5 & 458.5 & 177.2 & 531.3 & 217.7 & $12.1 \%$ & $22.0 \%$ \\
\hline Lubuskie & 165.1 & 138.0 & 168.6 & 130.3 & 202.4 & 155.2 & $22.5 \%$ & $12.5 \%$ \\
\hline Lódzkie & 485.4 & 251.2 & 475.9 & 244.7 & 559.2 & 283.7 & $15.2 \%$ & $12.9 \%$ \\
\hline Małopolskie & 710.7 & 248.2 & 659.6 & 151.2 & 833.3 & 159.7 & $17.3 \%$ & $-35.7 \%$ \\
\hline Mazowieckie & 418.9 & 235.9 & 395.8 & 241.4 & 477.5 & 248.7 & $14.0 \%$ & $5.4 \%$ \\
\hline Opolskie & 308.5 & 233.1 & 280.6 & 267.0 & 293.1 & 242.3 & $-5.0 \%$ & $3.9 \%$ \\
\hline Podkarpackie & 641.9 & 141.4 & 596.8 & 113.2 & 696.7 & 125.0 & $8.5 \%$ & $-11.6 \%$ \\
\hline Podlaskie & 358.6 & 262.1 & 358.1 & 289.7 & 412.6 & 238.3 & $15.1 \%$ & $-9.9 \%$ \\
\hline Pomorskie & 248.8 & 195.5 & 218.6 & 198.7 & 269.0 & 235.1 & $8.1 \%$ & $20.2 \%$ \\
\hline Śląskie & 485.4 & 180.1 & 427.3 & 168.7 & 518.3 & 172.9 & $6.8 \%$ & $-4.0 \%$ \\
\hline Świętokrzyskie & 568.6 & 193.8 & 569.7 & 169.7 & 696.7 & 189.2 & $22.5 \%$ & $-2.4 \%$ \\
\hline Warmińsko-mazurskie & 201.0 & 186.3 & 183.4 & 197.0 & 217.9 & 177.5 & $8.4 \%$ & $-4.8 \%$ \\
\hline Wielkopolskie & 349.1 & 337.3 & 321.4 & 330.4 & 376.1 & 327.6 & $7.7 \%$ & $-2.9 \%$ \\
\hline Zachodniopomorskie & 134.5 & 138.7 & 124.9 & 139.6 & 145.5 & 131.3 & $8.2 \%$ & $-5.3 \%$ \\
\hline
\end{tabular}

The graphs show the increase in both the intensity and the indicators expressing farm mechanization. It can be stated that the increase in production intensity affects the quantity of fixed assets, or that changes in farm mechanization affect the increase of intensity.

\section{CONCLUSIONS}

On the basis of the data analyzed, the impact of the intensity of production organization on farm mechanization in Poland cannot be clearly determined. Some relationships may be noticed, such as a general increase in the number of tractors and, what it involves, an increase in the level of tractive force, and a decrease in surface area per one tractor with the simultaneous increase in intensity. These relationships are not immediately noticeable for particular provinces.

Only a more detailed analysis based on research studies on a group of selected farms will allow to determine precisely the relationships between the examined features.

\section{REFERENCES}

Figurski J., Lorencowicz E.(2010). Ocena zmian wielkości ekonomicznej i intensywności organizacji produkcji w wybranych gospodarstwach rodzinnych. Roczniki Naukowe SERiA, XII(3), 72-75, http://rn.seria.com.pl/rn/category/45-12-3.html?download=2217,12-3-figurski

GUS (1995-2016). Roczniki Statystyczne Rolnictwa. www.stat.gov.pl

Jankowiak J., Bieńkowski J., Holka M. (2010). Wpływ intensywności produkcji rolnej na emisje azotu do środowiska. Roczniki Naukowe SERiA, XII (1), 65-69, http://rn.seria.com.pl/rn/category/43-12-1.html

Kluba M., Rudnicki R., Wiśniewski Ł. (2016). Intensywność organizacji produkcji a poziom mechanizacji rolnictwa w Polsce w świetle powszechnego spisu rolnego 2010. Studia Komitetu Przestrzennego Zagospodarowania Kraju PAN, 167, 214-230, http,//journals.pan.pl/Content/97834/mainfile.pdf

Kocira S. (2009). Intensywność organizacji produkcji a wielkość ekonomiczna i typ rolniczy gospodarstw. Journal of Agribusiness and Rural Development,3(13), 99-104, http,//www.jard.edu.pl/pub/13 3 2009.pdf 
Kołtun M. (2014). Intensity of production organization compared to the work factor in family farms. Agricultural Engineering 4(152), 143-150, DOI: http,//dx.medra.org/10.14654/ir.2014.152.089

Kopeć B. (1958). System gospodarczy jako wyznacznik struktury ekonomicznej w rejonie. Zagadnienia Ekonomiki Rolnej3(1), 29-61.

Kopeć B. (1987). Intensywność organizacji w rolnictwie polskim w latach 1960-1980. Roczniki Nauk Rolniczych 84(1), 7-27.

Kopiński J. (2009). Zmiany intensywności organizacji produkcji rolniczej w Polsce. Journal of Agribusiness and Rural Development,2(12), 85-92, http,//www.jard.edu.pl/pub/11_2_2009.pdf

Lorencowicz E. (2009). Intensywność organizacji produkcji a poziom mechanizacji prac w wybranych gospodarstwach rolnych Lubelszczyzny. Journal of Agribusiness and Rural Development,2(12), 111-117, http,//www.jard.edu.pl/pub/14_2_2009.pdf

Lorencowicz E., Mazurek K., Kocira S. (2017). Próba aktualizacji metody określania intensywności organizacji rolnictwa. Roczniki Naukowe SERiA, XIX(1), 92-98, DOI: 10.5604/01.3001.0009.8346

Malaga-Toboła U., Kocira S. (2013). Intensywność organizacji produkcji w ekologicznych i konwencjonalnych gospodarstwach mlecznych. Journal of Agribusiness and Rural Development, 1(27), 153-165, http,//www.jard.edu.pl/pub/14_1_2013_pl.pdf

Parafiniuk S. (2013). Dochodowość gospodarstw rodzinnych o różnej intensywności organizacji produkcji. Roczniki Naukowe SERiA,XV(4), 316-320, rn.seria.com.pl/rn/category/25-5-html?download=1208,15-4-parafiniu4

Polna M. (2009). Intensywność organizacji rolnictwa w Polsce w latach 1996-2002. Journal of Agribusiness and Rural Development,2(12), 157-165, http,//www.jard.edu.pl/pub/19_2_2009.pdf

Sawa J. (2009). Intensywność organizacji jako miernik ekologicznego zrównoważenia produkcji rolniczej. Journal of Agribusiness and Rural Development,2(12), 175-182, http,//www.jard.edu.pl/pub/21_2_2009.pdf

Szeląg-Sikora A. (2008). Zasoby użytków rolnych oraz wyposażenie w sprzęt rolniczy gospodarstw a poziom intensywności prowadzonej produkcji rolniczej. Inżynieria Rolnicza,9(107), 283-290, https,//yadda.icm.edu.pl/yadda/.../httpir_ptir_orgartykulypl107ir1072328pl.pdf

Szeląg-Sikora A., Cupiał M., Niemiec M. (2015). Intensity and labour consumption of integrated production in horticultural farms. Agriculture and Agricultural Science Procedia, 7, 249-254, DOI:https,//doi.org/10.1016/j.aaspro.2015.12.040

Szuk T. (2009). Wpływ mechanizacji na intensywność organizacji wybranych gospodarstw Dolnego Śląska. Journal of Agribusiness and Rural Development2(12), 233-240, http,//www.jard.edu.pl/pub/27_2_2009.pdf

Żak A. (2013). Zmiany obszarowe a intensywność gospodarowania w gospodarstwach indywidualnych. Roczniki Ekonomii Rolnictwa i Rozwoju Obszarów Wiejskich,100(2), 97-107, http,//www.wne.sggw.pl/czasopisma/pdf/RNR_2013_T100_z2.pdf 